\title{
ENSIKLOPEDIA FAUNA, INKUIRI TERBIMBING, DAN KEMAMPUAN BERPIKIR TINGKAT TINGGI DALAM PEMBELAJARAN FILUM INVERTEBRATA
}

\author{
Yohanes N. Bunga
}

Universitas Nusa Nipa

\begin{abstract}
Citasi: Bunga, Y.N. 2017. Ensiklopedia Fauna, Inkuiri Terbimbing, Dan Kemampuan Berpikir Tingkat Tinggi Dalam Pembelajaran Filum Invertebrata. Mangifera Edu Volume 2 Nomor 1. Hal 50-58
\end{abstract}

\begin{abstract}
ABSTRAK
Proses pembelajaran filum invertebrata yang terbatas pada media dan metode tertentu berakibat pada rendahnya kemampuan berpikir tingkat tinggi siswa. Masalah ini dapat diatasi dengan penggunaan ensiklopedia fauna sebagai media pembelajaran. Dalam penggunaannya guru berinovasi dengan menyusun lembar kerja siswa. Metode inkuiri terbimbing dipakai untuk menyelesaikan lembar kerja yang disiapkan. Kolaborasi ensiklopedia fauna, lembar kerja siswa dan penggunaan metode inkuiri terbimbing dapat meningkatkan kemampuan berpikir tingkat tinggi siswa. Siswa dengan kemampuan berpikir tingkat tinggi diharapkan dapat memanfaatkannya sebagai bekal untuk proses pendidikan selanjutnya dan dapat menjawab tuntutan kehidupan sehari-hari.
\end{abstract}

Kata kunci: siswa, filum invertebrata, inkuiri terbimbing, kemampuan berpikir tingkat tinggi

\section{PENDAHULUAN}

Hasil belajar merupakan gambaran atas rencana dan proses pembelajaran yang berlangsung di sekolah. Rencana dan proses pembelajaran yang berkualitas akan memberikan hasil belajar yang berkualitas namun jika rencana dan proses pembelajaran yang berlangsung kurang berkualitas tentu hasil belajar pun berkualitas rendah. Menurut Uno dan Koni (2014), menyatakan kualitas pembelajaran merupakan kualitas implementasi dari program yang telah dirancang sehingga peningkatan kualitas pembelajaran memerlukan upaya optimalisasi proses dan hasil belajar secara keseluruhan.

Berdasarkan data wawancara dengan guru Biologi SMA Negeri 2 Maumere, pembelajaran Biologi khususnya filum invertebrata masih sebagai materi pelajaran yang membosankan karena materi ini bersifat hafalan. Selain itu metode pembelajaran yang diterapkan masih berpusat pada guru, siswa pasif dalam proses pembelajaran, penggunaan literatur penunjang pembelajaran yang masih minim, dan kurang terlatihnya siswa untuk berpikir tingkat tinggi dalam pembelajaran sehari-hari. Sebagai akibat dari itu banyak siswa harus mengikuti remedial pada saat ulangan dan atau ujian. 
Salah satu langkah yang dilakukan untuk mengatasi permasalahan diatas adalah dengan menggunakan literatur penunjang pembelajaran dan metode yang merangsang keaktifan belajar siswa. Penerapan metode dan literatur penunjang pembelajaran yang mampu merangsang perkembangan kemampuan siswa perlu dilakukan secara berkesinambungan. Pertanyaan selanjutnya untuk kita adalah apakah penggunaan ensiklopedia fauna dengan metode inkuiri terbimbing dapat meningkatkan memampuan berpikir tingkat tinggi siswa?

\section{METODE PENELITIAN}

\section{Ensiklopedia Fauna}

Ensiklopedia merupakan media cetak yang dapat digunakan sebagai sumber penunjang pembelajaran. Ensiklopedia memuat berbagai peristilahan ilmu pengetahuan terbaru dan menjadi sumber belajar yang penting bagi siswa. Tugas guru saat pembelajaran adalah memberikan motivasi dan petunjuk yang tepat kepada siswa agar mereka mampu menggunakan ensiklopedia sebagaimana mestinya. Menurut Suwarno (2011), ensiklopedia pada dasarnya memiliki 3 tujuan yakni 1). Source of answer to fact question, ensiklopedia berfungsi sebagai sumber jawaban atas pertanyaan-pertanyaan yang memelukan data dan fakta. Ensiklopedia menyajikan materi-materi berdasarkan pengetahuan ataupun kejadian yang benar-benar ada; 2). Source of background service, merupakan informasi topik dan pengetahuan dasar yang masih memiliki hubungan dengan suatu obyek dan berguna untuk penelusuran lebih lanjut; 3). Direction service, merupakan layanan pengarahan untuk para pembaca kepada bahan-bahan yang akan dibahas pada topik-topik berikutnya.

Ensiklopedia fauna memuat gambar berbagai fauna di dunia disertai dengan keterangan-keterangan dan informasi yang menyeluruh dan lengkap. Hewan/fauna mulai dari invertebrata, ikan, amphibi, reptil, unggas, dan mamalia ada di dalamnya. Ensiklopedia fauna berisi pula materi tentang ciri-ciri hewan, kingdom hewan, ekologi, evolusi, adaptasi, cara hidup, habitat, kepunahan dan konservasi. Selain itu dilengkapi dengan daftar singkatan sistem metrik dan sistem imperial yang diyakini sangat membantu siswa dalam mengguna-kannya.

Dalam menggunakan ensiklopedia fauna, guru dapat melengkapinya dengan mengembangkan lembar kerja siswa. Pengembangan tersebut dapat berupa penyusunan soal-soal yang mendukung keterampilan berpikir tingkat tinggi siswa. Soal-soal yang disusunnya tersebut dapat direfleksikan dengan Taksonomi Bloom atau yang biasa dikenal dengan tingkatan pola berpikir C1 sampai dengan C6. Untuk dapat digunakan sebagai 
indikator tercapainya kompetensi belajar siswa, guru wajib mengembangkan instumen yang terencana secara sistematis. Penilaian yang dilakukan guru di kelas tidak hanya mengukur keberhasilan belajar siswa tetapi dapat berkontribusi dalam mengukur efektifitas belajar mengajar yang dilakukan di kelas (Reiner et. al, 2002).

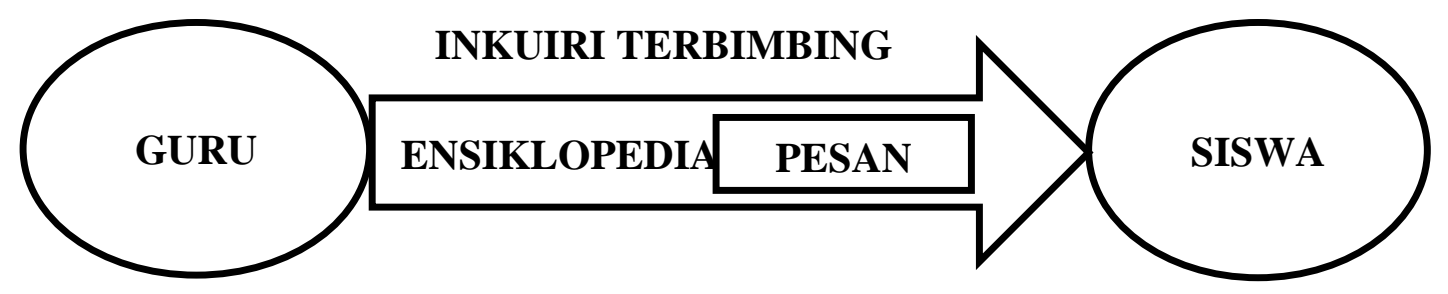

Gambar 1. Peran Ensiklopedia Dalam Proses Pembelajaran

Ensiklopedia fauna sebagai media pembelajaran maka peranannya sangat penting dalam proses belajar mengajar di kelas. Media sebagai sarana komunikasi yang mendukung proses komunikasi antara guru dan siswa serta antar siswa dalam kelas berjalan optimal. Proses belajar mengajar yang berjalan optimal dapat meningkatkan hasil belajar siswa. Demikian halnya ditegaskan dalam penelitian menggunaan media seperti penggunaan model sel tiga dimensi (Lazrowitz \& Naim, 2012), teknik animasi komputer (Karacop \& Doymus, 2013), penyusunan instrumen tes (Rofiah, Aminah \& Ekawati, 2013), dan pengembangan petunjuk praktikum (Sugiarti, 2011).

\section{Metode Inkuiri Terbimbing}

Inkuiri menurut Bruce \& Bruce (1992) merupakan suatu cara mengajarkan siswasiswa bagaimana belajar dengan menggunakan keterampilan, proses, sikap, dan pengetahuan berpikir rasional. Galileo Education Network (Alberta, 2004) mendefinisikan inkuiri sebagai proses dinamis yang terbuka dengan bertanya akan ketidaktahuan kemudian mencari untuk mengetahui dan memahami dunia. Metode inkuiri mendorong siswa terlibat aktif dalam kegiatan belajar mengajar, seperti aktif bertanya, aktif menyampaikan gagasan atau solusi. Pembelajaran dengan metode inkuiri memberikan perhatian utama pada proses pemetaan masalah dan kedalaman atas pemahaman masalah yang menghasilkan penyajian solusi atau jawaban yang valid dan meyakinkan (Anam, 2015).

Metode inkuiri dapat dilakukan dengan beberapa cara. Menurut Wenning (2005), inkuiri dibagi menjadi 3 tingkatan yakni 1). Discovery, pembelajaran discovery merupakan bentuk paling pokok dari pembelajaran berbasis inkuiri. Fokus pembelajaran discovery yakni menggunakan pengalaman sebagai kunci untuk memahami konsep; 2). Inkuiri terbimbing, dalam inkuiri terbimbing ini guru memberikan masalah kepada siswa. 
Selanjutnya guru membimbing siswa mencari cara terbaik untuk memecahkan masalah tersebut. Inkuri terbimbing sangat cocok untuk diterapkan dalam pembelajaran mengenai konsep-konsep dan prinsip-prinsip mendasar dalam bidang ilmu Biologi. Orlich, et. al (1998) menggarisbawahi beberapa karakteristik penting dari inkuiri terbimbing yaitu; siswa mengembangkan kemampuan berpikir melalui kerja observasi spesifik sehingga mampu membuat generalisasi, sasarannya adalah mempelajari proses mengamati suatu kejadian atau suatu obyek kemudian menyusun generalisasi yang sesuai, guru mengontrol kegiatan tertentu dari pembelajaran, setiap siswa berusaha membangun pola yang bermakna berdasarkan hasil observasi, kelas menjadi laboratorium pembelajaran, lazimnya sejumlah generalisasi tertentu akan diperoleh dari siswa, dan guru memberikan motivasi kepada siswa untuk mengkomunikasikan hasil generalisasinya sehingga dapat dimanfaatkan seluru siswa dalam kelas; 3). Inkuiri terbuka, guru cukup menyediakan wahana untuk pemecahan masalah. Sementara siswa meng-identifikasi dan merumuskan masalah, merancang, dan melaksanakan proses pemecahannya.

Metode inkuiri dapat memberikan gambaran fisik secara menyeluruh yang dapat meningkatkan pemahaman akan sesuatu masalah yang tidak dapat dipahami secara langsung. Dengan cara inkuiri materi pelajaran dapat dihubungkan dengan keadaan sekitar yang membutuhkan proses inkuiri untuk mendapatkan jawabannya. Untuk dapat memberikan gambaran tersebut metode inkuiri berfungsi sebagai; pedoman pengajaran, alat pengukur perasaan, bahasa umum untuk guru dan siswa, panduan bagi siswa, dan sebagai panduan untuk monitoring. Menurut Anam (2015), metode inkuri memiliki empat kelebihan yakni 1). Real life skill, siswa selalu didorong untuk aktif berpikir dan bekerja sehingga dapat mempelajari hal-hal penting namun dapat dengan mudah dilakukan; 2). Open-ended topic, siswa dapat belajar lebih banyak karena tema yang dipelajari tidak terbatas dan dapat bersumber dari mana saja; 3). Intuisif, imajinatif, inovatif, siswa memiliki kesadaran untuk belajar karena menjadi kebutuhannya sehingga akan dengan sekuat tenaga mengerahkan seluruh potensi yang dimiliki. Potensi itu dimulai dari kreatif hingga imajinatif; 4). Peluang melakukan penemuan, siswa akan mendapatkan hasil dari materi yang dipelajari dengan sendirinya. Dengan berbagai observasi dan eksperimen siswa berpeluang menemukan sesuatu hal yang baru.

Dalam penggunaannya seluruh tingkatan metode inkuiri memiliki beberapa fase yang sama. Lebih khusus inkuri terbimbing menekankan pada peran guru sebagai pembimbing untuk dapat terlaksananya penggunaan metode tersebut. Tahapan atau fase inkuri menurut Alberta (2004) yang dipadukan dengan Anam (2015) yakni 1). 
Perencanaan, pembelajaran yang mantap selalu mengutamakan perencanaan. Dalam pelaksanaannya, perencanaan dapat di revisi untuk mendapatkan rencana yang matang dan akurat. Dengan perencanaan yang matang dapat menimbulkan rasa optimis untuk langkah kerja selanjutnya. Dalam tahap perencanaan terdapat hal yang perlu diperhatikan yakni; menyusun ide-ide baru, membuat daftar kesepakatan atau kontrak kerja, mengubah tampilan atau ruang kelas; 2). Mendorong siswa untuk memberi respon, respon siswa dijadikan sebagai indikator proses pembelajaran. Tahap ini siswa mencari informasi terkait dengan topik yang akan dipelajari. Guru dapat berperan untuk untuk membangkitkan respon siswa dan mengajari keterampilan dan strategi untuk memilih informasi yang relevan pada siswa. Hal yang perlu diperhatikan dalam tahap ini yakni; membangun suasana dengan melontarkan pertanyaan yang memancing siswa untuk berpendapat, menantang siswa dengan memberi pertanyaan-pertanyaan spontan, dan menunda untuk terburu-buru memberi jawaban; 3). Mengelola/memproses seluruh informasi yang terkumpul, informasi yang diperoleh selama pembelajaran dikemas dan diolah ke dalam suatu bentuk yang aplikatif. Pada tahap ini tugas guru sebagai pembimbing adalah mengemas berbagai informasi ke dalam sebuah format yang padat, singkat, dan tepat. Hal yang dapat dilakukan untuk memproses informasi yang diperoleh adalah mendorong setiap siswa untuk memiliki pendapatnya sendiri dan melakukan uji coba atau pengujian; 4). Menciptakan penemuan baru, dalam tahap ini siswa merefleksi setiap opini dan teori yang ada sesuai dengan kebutuhan atau materi dalam pembelajaran. Hal ini dilakukan sebagai tahapan untuk memperoleh temuan baru. Rasa percaya diri siswa selalu dibangun oleh guru dengan membagikan keterampilan dan strategi yang memungkinkan untuk memperoleh temuan; 5). Berbagi, pada tahap ini setiap temuan terkait materi yang dipelajari disajikan kepada sesama termasuk guru. Guru mengajari strategi menyajikan hasil temuan, membangun sikap apresiatif dan selalu positif; 6). Evalusi, dilakukan untuk menggali lebih dalam masukan atau pendapat yang belum terungkap dalam proses pembelajaran berlangsung. Dalam sesi ini penyegaran kembali ingatan siswa terhadap poin-poin penting yang muncul dalam proses pembelajaran dan juga pendapat siswa yang bermakna. Dengan upaya ini siswa dapat merefleksikan kembali pengalaman mereka sehingga dapat merancang proses inkuiri pada materi yang akan datang.

Menerapkan model inkuiri dalam pembelajaran di kelas dapat menyebabkan perubahan dalam pengajaran dan memberikan hasil belajar yang baik. Hal ini telah dibuktikan dalam penelitian Figueroa (2011), yang menyatakan bahwa inkuiri dapat diimplementasikan sehingga dapat membantu pengembangan pengetahuan dan 
pemahaman oleh siswa. Sabourin et al. (2008) menyatakan siswa yang terlibat dalam pembelajaran berbasisi inkuiri mampu memecahkan masalah secara efektif. Penelitian Lazonder et al. (2008), menyatakan siswa yang melaksnakan pembelajaran berbasis inkuiri lebih berhasil dan efisen dalam pemberian tugas konkrit. Paidi (2010) menyatakan implementasi inkuiri terbimbing mampu meningkatkan kemampuan saintifik siswa. Hasil penelitian Budiono (2012) menyatakan bahwa penerapan model inkuiri terbimbing dapat meningkatkan kemampuan bepikir rasional siswa, dan Sugiarti (2011) menunjukan pembelajaran dengan metode inkuiri dapat meningkatkan hasil belajar, keterampilan, dan minat eksperimen siswa.

\section{Kemampuan Berpikir Tingkat Tinggi Siswa}

Siswa dinyatakan lulus dalam pembelajaran harus memenuhi kualifikasi standar. Kualifikasi standar lulusan tersebut dijelaskan dalam Permendikbud Nomor 54 tahun 2013. Dalam Permendikbud tersebut berisi tentang Standar Kompetensi Lulusan (SKL) yang digunakan sebagai acuan utama dalam pengembangan standar isi, standar proses, standar penilaian, standar pendidik dan tenaga kependidikan, standar sarana dan prasarana, standar pengelolaan, dan standar pembiayaan. Standar kompetensi yang wajib dipenuhi oleh siswa mencakup kualifikasi pengetahuan, sikap, dan keterampilan.

Permasalahan yang muncul dalam kehidupan sehari-hari manusia termasuk siswa membutuhkan kemampuan berpikir tingkat tinggi untuk mengatasinya. Proses berpikir sederhana membuat seseorang kurang dapat melatih keterampilan sintesis, analisis, evaluasi dan kreatif sehingga kurang cakap dalam menghadapi masalah yang kontekstual. Menurut Ennis (1993), memutuskan suatu tindakan, memecahkan masalah, berikir kritis, dan berpikir kreatif merupakan keterampilan berpikir tingkat tinggi. Siswa yang berkualitas tinggi diharapkan memiliki keempat pola pikir tersebut.

Keterampilan berpikir tingkat tinggi diperoleh melalui proses kerja yang melibatkan otak kiri dan otak kanan atau yang dikenal sebagai Corpus collasum (Rakhmat, 2011). Coepus collasum dapat dibentuk melalui proses latihan yang bekelanjutan, sesuai dengan penjelaskan dari Johnson (2011). Untuk pembentukannya, dalam pembelajaran filum invertebrata guru menyiapkan instrumen soal yang dapat melatih siswa untuk mengembangkan kemampuan berpikirnya. Tingkatan pola berpikir dapat direfleksikan dengan Taksonomi Bloom. Karena Taksonomi Bloom dianggap sebagai dasar untuk berpikir tingkat tinggi. Pemikiran ini didasarkan pada beberapa jenis pembelajaran memerlukan proses kognisi lebih tinggi daripada yang lain, namun memiliki manfaat yang 
lebih umum. Kemampuan berpikir tingkat tinggi dimulai dari C4 sampai dengan C6, yakni Menganalisis, Mengevaluasi, dan Mencipta.
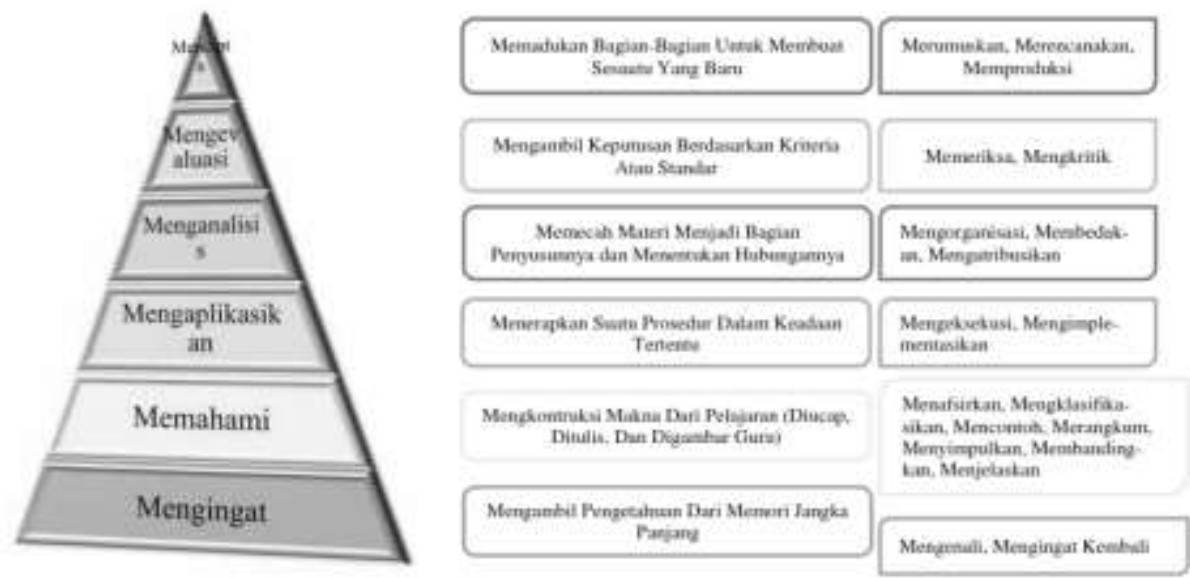

Gambar 2. Taksonomi Bloom Revisi

Menganalisis melibatkan proses memecah-mecah menjadi bagian-bagian kecil dan menentukan bagaimana hubungan antar bagian dan antara setiap bagian dan struktur keseluruhannya. Tujuan-tujuan pendidikan yang diklasifikasikan dalam menganalisis adalah menentukan potongan-potongan informasi yang relevan atau penting (membedakan), menentukan cara-cara untuk menata potongan-potongan informasi tersebut (mengorganisasikan, dan menentukan tujuan dibalik informasi tersebut (mengatribusikan) (Anderson \& Krathwohl, 2015). Menurut Anderson \& Krathwohl (2015), indikator yang digunakan untuk mengukur kemampuan menganalisis siswa meliputi, menganalisis informasi yang masuk dan membagi-bagi atau menstrukturkan informasi ke dalam bagian yang lebih kecil untuk mengenali pola atau hubungannya, mampu mengenali serta membedakan faktor penyebab dan akibat dari sebuah skenario yang rumit, dan mengidentifikasi atau merumuskan pertanyaan.

Setelah menganalisis tahap berpikir tingkat tinggi selanjutnya adalah mengevaluasi. Menurut Anderson \& Krathwohl (2015), mengevaluasi didefinisikan sebagai mengambil keputusan sebagai berdasarkan kriteria dan standar. Kriteria-kriteria yang digunakan adalah kualitas, efektivitas, efisiensi, dan konsistensi. Sehingga hasil sebuah analisis merupakan sesuatu yang benar-benar obyektif. Kategori mengevalusi mencakup prosesproses kognitif memeriksa (keputusan-keputusan yang akan diambil berdasarkan kriteria internal), dan melakukan kritik (keputusan-keputusan yang diambil berdasarkan keputusan eksternal). Labih lanjut Anderson \& Krathwohl (2015) menentukan indikator yang digunakan untuk mengukur kemampuan mengevaluasi siswa yakni; memberikan penilaian 
terhadap solusi, gagasan, dan metodologi dengan menggunakan kriteria yang cocok atau standar yang ada untuk memastikan nilai efektivitas atau manfaatnya, membuat hipotesis, mengkritik dan melakukan pengujian, dan menerima atau menolak suatu pernyataan didasarkan kriteria yang telah ditetapkan.

Setelah mampu mengevaluasi, siswa dituntut untuk menciptakan sesuatu yang baru atau menyusun kembali elemen-elemen menjadi sebuah keseluruhan yang koheren atau fungsional. Tujuan yang diklasifikasikan dalam mencipta adalah meminta siswa untuk membuat produk dengan mereorganisasi sejumlah eleman atau bagian menjadi sutau pola atau struktur yang tidak perna ada sebelumnya. Proses-proses kognitif yang terlibat dalam mencipta umumnya sejalan dengan pengalaman belajar siswa sebelumnya. Meskipun mengharuskan cara berpikir kreatif, mencipta bukanlah ekspresi kreatif yang bebas sama sekali atau dihambat oleh tuntutan-tuntutan tugas atau situasi belajar. Indikator yang dapat digunakan untuk mengukur kemampuan mencipta siswa yakni; membuat generalisasi suatu ide atau cara pandang sesuatu, merancang suatu cara untuk menyelesaikan suatu masalah, dan mengorganisasikan unsur-unsur atau bagian-bagian menjadi struktur baru yang belum perna ada sebelumnya (Anderson \& Krathwohl, 2015).

Perkembangan zaman selalu datang bersama dengan berbagai permasalahnnya, maka siswa nantinya akan berhadapan dengan berbagai permasalahan yang begitu rumit dan kompleks. Disinilah kemampuan berpikir tingkat tinggi dibutuhkan untuk menyelesaikannya. Kemampuan tersebut harus dilatih oleh guru selama proses pembelajaran, pemberian tugas dan evaluasi yang selalu menekankan kemampuan berpikir tingkat tinggi. Oleh karena itu guru pun seyogianya lebih banyak belajar dan berlatih baik sendiri maupun bersama rekan sejawat. Pemanfaatan berbagai metode dan media pun sangat dibutuhkan. Tanpa kemampuan berpikir tingkat tinggi siswa tidak akan mampu menyelesaiakn permasalahan yang datang serta akan tergerus arus globalisasi.

\section{KESIMPULAN}

Permasalahan belajar siswa dapat diatasi dengan melatih kemampuan berpikir siswa. Penggunaan media ensiklopedia fauna dalam pembelajaran dengan metode inkuiri terbimbing dilengkapi lembar kerja siswa dapat menjadi alternatif peningkatan kemampuan berpikir tingkat tinggi siswa. Berbekal kemampuan berpikir tingkat tinggi, siswa dapat menyelesaikan permasalahan dalam pembelajaran maupun dalam kehidupan sehari-hari yang semakin kompleks. 


\section{DAFTAR PUSTAKA}

Alberta. 2004. Focus on Inquiry: A Teacher's Guide to Implementing Inquiry-based Learning. Alberta Learning Web site at http://learning.gov.ab.ac.cak/k_12/curriculum/ bySubject/focusinquiry.pdf

Anam, Khoirul. 2015. Pembelajaran Berbasisi Inquiri, Metode Dan Aplikasi. Yogyakarta: Pustaka Pelajar

Anderson, Lorin W. \& David R. Krathwohl. 2015. Kerangka Landasan Untuk Pembelajaran, Pengajaran, Dan Asesmen. Terjemahan Agung Prihantoro. Yogyakarta: Pustaka Pelajar

Budiono, Eko. 2012. Penerapan Model Pembelajaran Guided Inquiry Untuk Meningkatkan Kemampuan Berpikir Rasional Siswa Kelas VII F SMP Negeri 5 Surakarta. Skripsi. UNS

Bruce, W. C. \& J. K. Bruce. 1992. Teaching with Inquiry. Maryland: Alpha Publishing Company, Inc.

Ennis, R. H. 1993. Critical Thinking Assesment. College of education, The Ohi State University, 32 (3): 44-49

Figueroa, Maria. 2011. An Inquiry Into Inquiry Science Teaching In Colombia. A Dissertation. Stanford University

Johnson, E. B. 2011. Contextual Teaching and Learning. Terjemahan Ibnu Setiawan. Bandung:MLC 